\title{
On Cucuys in Bird's Feathers: A Counterstory as Parable
}

\author{
Aja Y. Martinez
}

Aja Y. Martinez is assistant professor of writing and rhetoric at the University of North Texas. Dr. Martinez's greater body of work and expertise in critical race counterstory is a methodological contribution to race critical studies through the well-established framework of critical race theory (CRT). Her single-authored monograph, Counterstory: The Writing and Rhetoric of Critical Race Theory, has been published with Studies in Writing and Rhetoric.

ritical race theorist Richard Delgado has outlined several generic styles counterstories can take: chronicles, narratives, allegories, parables, and dialogues (2438). In this essay I extend his discussion of counterstory by exploring the power of the parable-a nod to writers like Octavia Butler and to writers of my heritage, such as Ana Castillo, who invoke magical realism with their words. I made the methodological choice to write about the topics of mentorship and writing/publishing collaborations as counterstory because this narrative approach provides me as an author a flexibility with which to discuss key concerns and to present data in ways that do not directly identify or name persons, organizations, institutions, or fields to which to apply the topics and lessons of this parable. Instead, this counterstory reviews the central topics of this story-as-parable while maintaining pressure on the audience to (based on their own lived actions and experiences) read/see themselves in the fictional characters within. In the case of this essay, counterstory expands the voice, style, citation practice, and genre possibilities for a discussion of mentorship and writing/publishing collaborations I maintain as an invitation to this conversation for my audience-particularly for audience members who maintain the power and privilege of working with emerging scholars (i.e., graduate program professors and senior scholars).

In all, critical race theory (CRT) counterstory functions as a method for writers to intervene in research methods that would form master narratives based on ignorance and assumptions about minoritized and/or vulnerable populations, such as graduate students and junior professionals. Through the formation of counterstories, those stories that document the persistence of inequities and other forms of subordination told "from the perspectives of those injured and victimized by its legacy" (Yosso 10), voices with less power or platform become central in the researching and relating of our own experiences. As a writing method, critical race counterstory is a theoretically grounded research approach that draws on an interdisciplinary approach with roots in ethnic studies, women's studies, sociology, history, the humanities, and the law. Counterstory challenges privilege and recognizes that experiential knowledge of minoritized and/or vulnerable populations is legitimate and critical to understanding the structural power imbalances and abuses alive and well within our professional lives, organizations,

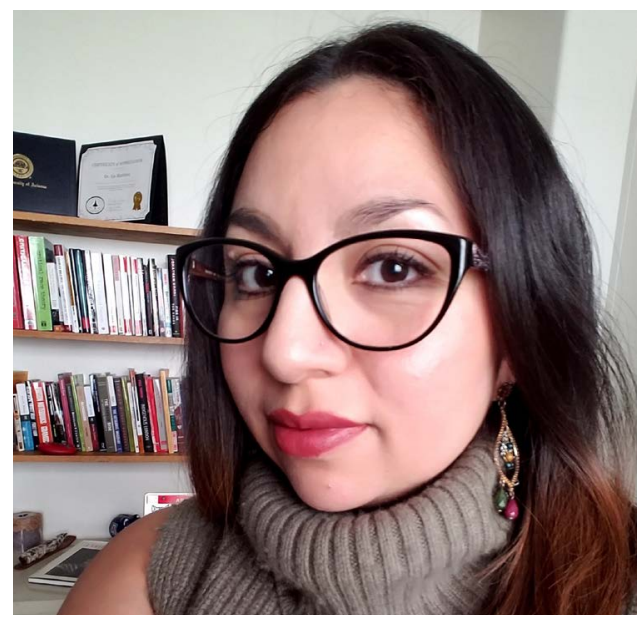

\section{Abstract}

This counterstory reviews central topics of mentorship and writing/publishing collaborations as parable. While maintaining pressure on the audience to read/ see themselves in the fictional characters within, this counterstory-as-parable expands the voice, style, citation practice, and genre possibilities for discussions that are difficult to engage due to power imbalances and precarity within the profession for graduate students and junior professors. This counterstory as parable is an invitation to discuss the important topics of mentorship and writing/publishing, particularly for audience members who maintain the power and privilege of working with emerging scholars (i.e., graduate program professors and senior scholars).

\section{Keywords}

critical race theory, counterstory, mentoring, publishing, writing 
institutions, and mentoring relationships. Counterstory, then, functions as a method to empower minoritized and/or vulnerable populations with a skill set with which to intervene in the erasures accomplished in master narratives. In all, the parable approach of this essay discusses and shows how counterstory as a method can apply toward a field-wide conversation of mentorship and writing/publishing collaborations.

\section{COUNTERSTORY AS PARABLE}

Once upon a time, there was a small but strong and loving familia of pájaritos. The members of this small family of birds were not related by birth but by a shared and acknowledged lineage, so they each displayed very different feathers, beaks, shapes, and sizes. These pájaritos sang a beautiful harmonious song, and they named themselves Nos Golondrinxs de la Verdad but were known to outsiders as just The Gols. Nos Golondrinxs embraced the diversity amongst their small flock, and they cared about justice and access for all birds to a good life with plenty of nourishing birdseed to eat, plenty of resources to build a nest, and plenty of air and space to voice their beautiful individual and collective songs.

As the years passed, Nos Golondrinxs grew and multiplied, and within each new generation there emerged new beautiful songs, projected further than the generations of pájaritos before. These new songs were strong and beautiful only because they built on the foundation and knowledge of Nos Golondrinxs' elders who came before them. Outsider flocks, more robust in their size (in stature and collective numbers) who, had previously paid Nos Golondrinxs no mind due to their smaller size, became increasingly aware of this familia and began to wonder from whence they drew their collective strength, knowledge, and songs. Some Outsider flocks even began to sing songs about The Gols, but these songs were often sung for or about the familia, resulting in songs that fell on the ears of Nos Golondrinxs as out of tune and disharmonious with the songs the familia sang about themselves. Without inviting Nos Golondrinxs to sing with them, these Outsiders just never got the tunes right.

As additional time passed and as more pájaritos joined Nos Golondrinxs' flock, a Delegation within the familia formed through their collective insecurity and jealousy toward the beautiful songs being sung by their fellow pájaritos. Although this Delegation of pájaritos were welcome and accepted with love and openness to Nos Golondrinxs, unbeknownst to the familia, members of this Delegation often flew to Outsider territories and fed on birdseed poisoned with hate and resentment. This food nourished their bodies but clouded their minds. This birdseed convinced members of the Delegation that their familia in Nos Golondrinxs were their competition for food, nesting materials, and notes for new beautiful songs and thus were not to be trusted. Because members of the Delegation increasingly viewed members of their familia as competitors instead of collaborators, and because this poisoned birdseed clouded their brains and slowly deteriorated their vocal cords, the Delegation, who became increasingly incapable of fashioning new notes, composing new songs, or singing in harmony, devised a strategy.

As new pájaritos joined the flock, the Delegation were strategically amongst the first to welcome these young birds to the familia. Seeing these new birds as an opportunity to hopefully sing once more, the Delegation offered their "mentorship" to these eager new pájaritos. Excited about the prospect of being welcomed so enthusiastically and (seemingly) lovingly to a vibrant and active familia, the new pájaritos were only too willing to jump at the opportunity to collaborate on new songs when offered the opportunity by the Delegation. As is well known, the very lifeblood and survival of pájaritos hinges on the creation of songs. Thus, the opportunity to make music with more experienced pájaritos was too important an offering to pass up.

However, as the collaborations between new pájaritos and "mentors" from the Delegation progressed, the new pájaritos began to notice their Delegation collaborators did not produce notes. Troubled but unsure of how to broach this concern with their "mentors" - who after all had been making music within Nos Golondrinxs for a very long time- - the new pájaritos did their best to contribute their best notes and to sing their beautiful songs. When other members of Nos Golondrinxs praised the new pájaritos and their "mentors" for the beautiful new songs, the new pájaritos noted the way their "mentors" reveled in the praise and never made known how little they contributed to these new songs. Eventually, as the new pájaritos grew in wisdom and experience, they tired of these one-sided collaborations with their Delegation "mentors" and made moves to sever ties. Enraged by being cut off from their song fonts, Delegation members often flew off to Outsider spaces to publicly lash out at their former mentees. However, because members of the Delegation cannot sing beautiful songs without the labor and innovation of new pájaritos, their lashing out sorely lacks in harmonious veracity and sounds much more like the song of a seagull: "Mine. Mine. Mine." But to the ears of an Outsider, their songs sound like la Verdad.

Thus, the moral of this story is: Beware the members of the Delegation who lurk amongst your flock and familia, preying on your most vulnerable in the guise of "mentorship." Take care of the new pájaritos. Our silence will not protect us and we cannot know about the Delegation through whispers and a lack of accountability. Call their shit out, and if warranted and deserved, do it with compassion and care. The health of the collective is central if we are to survive the Outside(rs). And above all, make beautiful music in the spirit of solidarity, coalition, and comadrismo (Licona and Chávez; Ribero and Arellano). Everything/anything else is just seagull squawk.

The End 


\section{Works Cited}

Butler, Octavia E. Parable of the Sower. Hachette Book Group, 1993.

Castillo, Ana. So Far from God. W.W. Norton, 1993.

Delgado, Richard. "Storytelling for Oppositionists and Others: A Plea for Narrative." Michigan Law Review, vol. 87, no. 8, 1989, pp. 2411-2441. https://doi.org/10.2307/1289308

Licona, Adela C. and Karma R. Chávez. "Relational Literacies and their Coalitional Possibilities." Peitho, vol. 18, no. 1, 2015, pp. 96-107.

Lorde, Audre. "The Transformation of Silence into Language and Action." Sister Outsider: Essays and Speeches. The Crossing Press, 2007, pp. 40-44.

Ribero, Ana Milena and Sonia C. Arellano. "Advocating Comadrismo: A Feminist Mentoring Approach for Latinas in Rhetoric and Composition." Peitho, vol. 21, no. 2, 2019, pp. 234-256.

Yosso, Tara J. Critical Race Counterstories along the Chicana/ Chicano Educational Pipeline. Routledge, 2006. 